\title{
Evolution of the Merchantability and the Level of Ochratoxin A of Ivorian Cocoa Beans from Production Areas during the Harvest Season
}

\author{
Adama Coulibaly ${ }^{1,2}$, Ardjouma Dembele ${ }^{1}$, Henri Marius Godi Biego ${ }^{2}$, Nahoule Silue $^{1} \&$ A. Abba Toure ${ }^{3}$ \\ ${ }^{1}$ Central Laboratory of Agrochemistry and Ecotoxicology, Cote d'Ivoire \\ ${ }^{2}$ Laboratory of Biochemistry and Food Science, UFR Biosciences, University of Cocody-Abidjan, Cote d'Ivoire \\ ${ }^{3}$ Environment and Health Department, Institute Pasteur, Cote d'Ivoire \\ Correspondence: Henri Marius Godi Biego, Laboratory of Biochemistry and Food Science, UFR Biosciences, \\ University of Cocody-Abidjan, Cote d'Ivoire. E-mail: biegoh3@yahoo.fr
}

Received: April 5, 2012 Accepted: May 8, 2012 Online Published: July 20, 2012

doi:10.5539/sar.v1n2p178 URL: http://dx.doi.org/10.5539/sar.v1n2p178

\begin{abstract}
This study aims to investigate the evolution, throughout the harvest season, of merchantability criteria and Ochratoxin A (OTA) levels in cocoa beans produced in Cote d'Ivoire. To this end, 567 samples of cocoa beans, collected in 6 production areas during the 2007-2008 season, were analyzed. Merchantability and OTA levels were determined respectively according to the Ivorian Coffee and Cocoa stock exchange standards and the European Community regulation related to the analytical methods for the control of mycotoxins levels in foodstuffs (EC 401/2006). Concerning merchantability, a significant difference at $5 \%$ risk was revealed between the values of moisture, graining and grades. As regards OTA levels, the concentrations obtained ranged from $0.41 \mu \mathrm{g} / \mathrm{kg}$ to $1.36 \mu \mathrm{g} / \mathrm{kg}$ of cocoa beans with an average concentration of $0.69 \mu \mathrm{g} / \mathrm{kg}$. These concentrations are all below the maximum value set at $2 \mu \mathrm{g} / \mathrm{kg}$ by the European Commission. Moldy and/or slaty beans are chiefly answerable for the depreciation of cocoa beans marketability. These results served to devise a map summarizing the quality of Ivorian cocoa beans. Needless to say, this map is just a representation of a situation at a given time, and should therefore contribute to take up decisions relevant to the application of good production and postharvest processing practices in the country's quest for cocoa beans of prime quality.
\end{abstract}

Keywords: Ochratoxin A, cocoa bean, merchantability, mapping, Cote d'Ivoire

\section{Introduction}

Cote d'Ivoire holds a prominent place on the international market for cocoa. Cocoa cultivation accounts for 10\% of the Gross National Product and provides a wide range of odd jobs for quite a few people from many rural communities (Bonjean \& Bruns, 2008). Liberalization has led to a radical change in the organization of cocoa production and selling. It has spurred the abandonment of the principle of guaranteed price to producers and the emergence of private operators exacerbating the shrinkage in income and vulnerability of farmers (Bonjean \& Bruns, 2001). Liberalization has also led to the abandonment of the orchards, the cutback in cocoa production and, most worrying, the crescendo of parasite pressure which gives rise to a significant degradation of the quality of cocoa beans (Ruf, 2000; Pauline et al., 2008). Poorly conducted post-harvest treatments can lead to the dissemination of toxin-producing molds such as Aspergillus and Penicillium responsible for the production of ochratoxin A for instance (Bastide et al., 2006). OTA is known to be nephrotoxic, teratogenic, and immunosuppressive (Moré \& Galtier, 1974; Dwidedi \& Burns 1984; Boorman et al., 1984; Categnaro et al., 1998; Categnaro, 1999). It was classified as a carcinogen of the Group 2B by the International Agency for Research on Cancer (World Health Organization [WHO], 1993) and may also be implicated in several human diseases, such as the Balkan endemic nephropathy (Petrova et al., 1988) and also in the development of tumors of the urinary and kidney tracts in some countries of the Maghreb (Maaroufi et al., 1996; Waffa et al., 1998).

Of course, OTA was found in both Ivorian ports and production areas at respective levels of $0.97 \mu \mathrm{g} / \mathrm{kg}$ and 0.19 $\mu \mathrm{g} / \mathrm{kg}$ (Lainé, 2001; Dembele et al., 2009), but there are unfortunately no studies on the distribution of OTA and the marketability of cocoa beans from the production areas. We have therefore initiated this study to investigate the evolution, throughout the harvest season, of merchantability criteria and Ochratoxin A levels in cocoa beans 
produced in Côte d'Ivoire and establish a map of Ivorian cocoa beans quality.

\section{Material and Methods}

\subsection{Sampling}

Table 1. Distribution of samples by zones of study

\begin{tabular}{llll}
\hline Zones & Regions & Departments & Number of samples collected \\
\hline \multirow{2}{*}{ Zone 1} & Haut Sassandra & Daloa, Issia & \\
& Fromager & Gagnoa, Bouafle, & 144 \\
& Marahoue & Sinfra & \\
Zone 2 & Lacs & Yamoussoukro & \\
& & Tiebissou & 32 \\
& Moyen Comoe & Toumodi & \\
& N'zi Comoe & Abengourou & \\
Zone 3 & Sud Comoe & Bongouanou & \multirow{2}{*}{54} \\
& Agneby & Daoukro, Dimbokro & \\
& & Grand-Bassam & \\
Zone 4 & Lagunes & Alepe, Dabou & \multirow{2}{*}{69} \\
& & Tiassale & \\
Zone 5 & Bas-Sassandra & Sassandra & \\
& & Soubre, Divo & 226 \\
Zone 6 & Zandama & Lakota & \\
& & Bondoukou & 42 \\
\hline
\end{tabular}

Sampling was carried out according to a spatial coverage of all the Ivorian production areas of cocoa beans. On the basis of data from the Ivorian Coffee and Cocoa stock exchange (Bourse du Café et du Cacao [BCC], 2009), 12 of the 14 production areas have been grouped into six zones as summarized in Table 1. In each zone, samples were collected according to the amount of production of the area. Thus, were part of a zone, regions and departments of high production (BCC, 2009). For this study 567 samples of cocoa beans were collected from November 2007 to March 2008 according to the European Community regulation (EC 401/2006) (European Communities [EC], 2006).

\subsection{Determination of Cocoa Beans Marketability}

According to Ivorian regulation (BCC, 2009), three parameters are taken into account when it comes to assess the merchantability of cocoa beans: the moisture content, the graining and the classification in grades (Table 2). The moisture content of cocoa beans was determined with the help of an oven at $105^{\circ} \mathrm{C}$ until constant weight (Association of Official Analytical Chemists [AOAC], 1990).

The graining was determined by counting the number of beans in $100 \mathrm{~g}$ of whole cocoa beans free of any foreign materials. Finally, the classification in grades was related to the percentage of defective cocoa beans for $100 \mathrm{~g}$ of whole cocoa beans. To this end, $100 \mathrm{~g}$ of whole cocoa beans were cut lengthwise through the middle with a bean knife brand STANLEY, to expose a maximum cut surface of cotyledons. Visual examination of the inner of the two half-beans highlights possible flaws (ISO/1114) (International Standard Organization [ISO], 1977). 
Table 2. Cocoa beans merchantability standard in Cote d'Ivoire

\begin{tabular}{|c|c|c|c|}
\hline \multicolumn{4}{|c|}{$\begin{array}{l}\text { MOISTURE CONTENT } \\
\text { MONT }\end{array}$} \\
\hline \multicolumn{3}{|c|}{ Maximum value allowed } & $8 \%$ \\
\hline \multicolumn{4}{|c|}{ NUMBER OF BEANS PER $100 \mathrm{~g}$ OF COCOA BEANS } \\
\hline Maximum value & & & 105 \\
\hline \multicolumn{4}{|l|}{ GRADES } \\
\hline \multirow{2}{*}{ Grade } & \multirow{2}{*}{ Moldy } & \multirow{2}{*}{ Slaty } & Defective \\
\hline & & & Moth + Germinated + Flat \\
\hline Grade I (GI) & $\leq 3 \%$ & $\leq 3 \%$ & $\leq 3 \%$ \\
\hline Grade II (GII) & $>3 \%$ and $\leq 4 \%$ & $3 \%$ and $\leq 8 \%$ & $>3 \%$ and $\leq 6 \%$ \\
\hline Low grade (LG) & $>4 \%$ & $>8 \%$ & $>6 \%$ \\
\hline
\end{tabular}

\subsection{Determination of OTA Levels in Cocoa Beans}

\subsubsection{Extraction of Ochratoxin A}

The entire sample was crushed in a hammer mill to obtain a homogeneous fine grind. In a Nalgene jar containing $15 \mathrm{~g}$ of homogenate, $150 \mathrm{~mL}$ of aqueous methanol-bicarbonate $1 \%(\mathrm{~m} / \mathrm{v} ; 50: 50)$ were added. The mixture was homogenized by Ultra-Turax for 3 minutes and the homogenate was centrifuged at $5000 \mathrm{rpm}$ for 5 minutes at $4^{\circ} \mathrm{C}$. The supernatant was filtered through filter paper into tubes of $25 \mathrm{~mL}$. To $11 \mathrm{~mL}$ of filtrate were added 11 $\mathrm{mL}$ of saline phosphate buffered (PBS) at $\mathrm{pH}$ 7.3. Immunoaffinity columns brand Ochraprep and R-Biopharm were conditioned with $10 \mathrm{~mL}$ of PBS. Purification of $20 \mathrm{~mL}$ of the mixture was made on immunoaffinity columns and OTA extraction was performed with two volumes of $1.5 \mathrm{~mL}$ of PBS at a flow rate of $5 \mathrm{~mL} / \mathrm{minute}$. The resulting sample was packed in a chromatographic tube and the analysis of OTA was made by HPLC using the European community regulation (EC 401/2006) (EC, 2006).

\subsection{Apparatus}

A gas chromatograph HPLC brand Shimadzu coupled to a fluorescence detector was used and the operating conditions are described in Table 3.

Table 3. HPLC analytical conditions

\begin{tabular}{ll}
\hline Precolumn & Shim-pack GVP-ODS $10 \times 4.6 \mathrm{~mm}$ \\
\hline Column & Shim-pack GVP-ODS $250 \mathrm{~mm}$ x $4.6 \mathrm{~mm}$ \\
Detector & Flurescence, $\lambda$ excitation: $330 \mathrm{~nm}, \lambda$ emission: \\
Mobile phase & $460 \mathrm{~nm}$ \\
Injected volume & Acetonitrile/Water/Acetic acid (99/99/2) \\
Flow rate & $100 \mu \mathrm{L}$ \\
Column temperature & $40^{\circ} \mathrm{C} /$ minute \\
Rinsing solvent & Acetonitrile \\
Analysis duration & 12 minutes \\
\hline
\end{tabular}

\subsection{Statistical Analysis}

The averages were calculated with their standard deviations to assess OTA levels, moisture content, graining and grades of cocoa beans. The squared coefficient of Bravais-Pearson was calculated to assess the correlation between OTA and the criteria for marketability. The homogeneity of means (OTA, moisture content and graining) was determined by a one or two-way analysis of variance (sampling location or period and/or grade) through Fisher test, using SPSS 12 software at 5\% risk. 


\section{Results}

\subsection{Merchantability of Cocoa Beans}

The results of the marketability of cocoa beans are shown in Table 4. The average moisture contents were comprised between 6.5 and $9.9 \%$ with a value of $8.9 \%$ for all zones combined. The homogeneity of the average moisture contents performed by a one-way analysis of variance (sampling site), through Fisher-test revealed a significant difference at $5 \%$ risk, that is, the humidity varies from one zone to another. Higher rates are observed for zones 5,1 and 2, with respective averages of $9.9 \%, 9.4 \%$ and $8.9 \%$. This variability is also observed in the percentage of samples with moisture content above the limit value of $8 \%$ set by the Ivoirian regulation (BCC, 2009). This percentage is between 19 and $74 \%$ with an average of $56 \%$.

Table 4. Merchantability results

\begin{tabular}{|c|c|c|c|c|}
\hline \multicolumn{5}{|c|}{ MOISTURE CONTENT (\%) } \\
\hline \multirow{2}{*}{ ZONES } & \multirow{2}{*}{ AVERAGE } & \multirow{2}{*}[\text{Min-Max}]{} & \multicolumn{2}{|c|}{ Proportion of sample* } \\
\hline & & & \multicolumn{2}{|l|}{ Moisture $>8 \%$} \\
\hline ZONE 1 & $9.4 \pm 2.6 \mathrm{ab}$ & $5.0-20.0$ & \multicolumn{2}{|l|}{57} \\
\hline ZONE 2 & $8.9 \pm 1.6 \mathrm{~b}$ & $6.6-13.7$ & \multicolumn{2}{|l|}{63} \\
\hline ZONE 3 & $7.6 \pm 1.7 \mathrm{c}$ & $5.0-12.7$ & \multicolumn{2}{|l|}{33} \\
\hline ZONE 4 & $7.2 \pm 1.6 \mathrm{c}$ & $5.0-12.4$ & \multicolumn{2}{|l|}{28} \\
\hline ZONE 5 & $9.9 \pm 2.4 \mathrm{a}$ & $5.0-20.0$ & \multicolumn{2}{|l|}{74} \\
\hline ZONE 6 & $6.5 \pm 1.6 \mathrm{~d}$ & $5.0-11.0$ & \multicolumn{2}{|l|}{19} \\
\hline AVERAGE & $8.9 \pm 2.6 \mathrm{~b}$ & $5.0-20.0$ & \multicolumn{2}{|l|}{56} \\
\hline \multicolumn{5}{|c|}{ GRAINING (Number of beans for $100 \mathrm{~g}$ of cocoa beans) } \\
\hline ZONES & $\begin{array}{l}\text { Average } \\
\text { (Beans } / 100 \mathrm{~g})\end{array}$ & [Min-Max] & \multicolumn{2}{|c|}{$\begin{array}{l}\text { Proportion of sample* } \\
\text { Graining }>105\end{array}$} \\
\hline ZONE 1 & $102 \pm 21 \mathrm{a}$ & $78-193$ & \multicolumn{2}{|l|}{31} \\
\hline ZONE 2 & $107 \pm 22 \mathrm{a}$ & $83-172$ & \multicolumn{2}{|l|}{38} \\
\hline ZONE 3 & $96 \pm 4 \mathrm{~b}$ & $84-117$ & \multicolumn{2}{|l|}{7} \\
\hline ZONE 4 & $100 \pm 14 \mathrm{a}$ & $82-149$ & \multicolumn{2}{|l|}{26} \\
\hline ZONE 5 & $102 \pm 14 \mathrm{a}$ & $81-158$ & \multicolumn{2}{|l|}{29} \\
\hline ZONE 6 & $100 \pm 15 \mathrm{a}$ & $72-141$ & \multicolumn{2}{|l|}{24} \\
\hline AVERAGE & $101 \pm 16 \mathrm{a}$ & $72-193$ & \multicolumn{2}{|l|}{27} \\
\hline \multicolumn{5}{|c|}{ CLASSIFICATION IN GRADES (\%) } \\
\hline ZONES & $\begin{array}{l}\text { GRADE I } \\
\text { (GI) }\end{array}$ & $\begin{array}{l}\text { GRADE II } \\
\text { (GII) }\end{array}$ & $\begin{array}{l}\text { LOW-GRADF } \\
\text { (LG) }\end{array}$ & $\begin{array}{l}\text { EXPORTABLES } \\
(\mathrm{GI}+\mathrm{GII})\end{array}$ \\
\hline ZONE 1 & 36 & 42 & 22 & 78 \\
\hline ZONE 2 & 37 & 44 & 19 & 81 \\
\hline ZONE 3 & 30 & 50 & 20 & 80 \\
\hline ZONE 4 & 35 & 36 & 29 & 71 \\
\hline ZONE 5 & 25 & 36 & 39 & 61 \\
\hline ZONE 6 & 24 & 43 & 33 & 67 \\
\hline AVERAGE & 30 & 40 & 30 & 70 \\
\hline
\end{tabular}

Means in a column, for each criterion, followed by the same letter are not significantly different $(\mathrm{p}<0.05)$

*Percentage of samples with moisture or graining levels exceeds the values shown.

Results for graining indicated a number of beans per $100 \mathrm{~g}$ of cocoa beans ranging from 96 to 107 with an average of 101 beans for all zones combined. The homogeneity of the average values for graining was performed by a one-way analysis of variance (sampling site), through the Fisher test and revealed a significant difference at $5 \%$ risk. Except for zone 3 which displays a graining value lower than all the values obtained, all the other zones 
have statistically similar values. The proportion of samples with a graining value higher than the limit value of 105 beans set by the Ivorian regulation (BCC, 2009) varies from one zone to another. Zones 2,1 and 5 present the highest rates: $38 \%, 31 \%$ and $29 \%$ respectively. The classification in grades showed that the proportion of exportable samples was between $61 \%$ and $81 \%$ for the six zones with an average of $70 \%$. However, results for zones 5 and 6 (respectively $61 \%$ and $67 \%$ of exportable samples) are below this average (Table 4).

\subsection{Major Defects Responsible for the Impairment of the Marketability of Ivorian Cocoa Beans}

Samples classified Grade 2 (GII) and Low- Grade (LG) are of inferior quality. Table 5 shows the distribution of defects in these lots. Defective beans, slaty and slaty-defective are responsible at respectively $55 \%, 19 \%$ and $15 \%$ for the depreciation of the marketability of the lots classified GII. Concerning Low- Grade samples (LG), moldy, slaty, defective and moldy-defective beans are responsible at respectively $39 \%, 10 \%, 27 \%$ and $19 \%$ for the depreciation of the marketability.

Table 5. Distribution of defects in the samples classified Grade II and Low-Grade for all zones

\begin{tabular}{lcc}
\hline PARAMETERS & Grade II (\%) & Low-Grade (\%) \\
\hline MOLDY & 3.0 & 39 \\
SLATY & 19 & 10 \\
DEFECTIVE & 55 & 27 \\
MOLDY-SLATY & 1.0 & 3.0 \\
MOLDY-DEFECTIVE & 4.0 & 19 \\
SLATY-DEFECTIVE & 15 & 1.0 \\
MOLDY-SLATY-DEFECTIVE & 3.0 & 1.0 \\
\hline
\end{tabular}

\subsection{Ochratoxin A Levels in Cocoa Beans}

The limits of detection and quantification were respectively $0.05 \mu \mathrm{g} / \mathrm{kg}$ and $0.20 \mu \mathrm{g} / \mathrm{kg}$. The coefficients of variation for repeatability and reproducibility were respectively $0.26 \%$ and $5.67 \%$. These results account for the reliability of the method used to determine OTA levels in cocoa beans samples.

Table 6 presents the average concentrations and the range for OTA levels found in samples from the six zones considered. The average concentrations varied between 0.41 and $1.36 \mu \mathrm{g} / \mathrm{kg}$ with an average of $0.69 \mu \mathrm{g} / \mathrm{kg}$. Contamination varies from one zone to another. In fact the homogeneity of the concentrations of OTA performed by a one-way analysis of variance (sampling site), through the F-test revealed a significant difference at $5 \%$ as shown in Table 6. The highest concentrations were observed in zones 2, 6 and 4 with respective averages of 1.36 $\mu \mathrm{g} / \mathrm{kg}, 0.77 \mu \mathrm{g} / \mathrm{kg}$ and $0.75 \mu \mathrm{g} / \mathrm{kg}$. This variability is also observed in the proportion of samples with OTA concentration above the limit value of $2 \mu \mathrm{g} / \mathrm{kg}$ advocate by the European Union (EC, 2006; Codex Alimentarius [CA], 2011). The proportion of over contaminated samples was between $2 \%$ and $13 \%$ with an average of $6 \%$. The highest proportions (7\%, 9\% and 13\%) are observed respectively in zones 5, 4 and 2. OTA was not detected in $15 \%$ of all the samples collected.

Table 6. Ochratoxin A levels in cocoa beans (Concentration: $\mu \mathrm{g} / \mathrm{kg}$ )

\begin{tabular}{lllcc}
\hline \multirow{2}{*}{ ZONES } & \multicolumn{2}{l}{ OCHRATOXIN A LEVELS } & \multicolumn{2}{c}{ Proportion of sample (\%) } \\
& Average & {$[$ Min-Max] } & $<\mathrm{LD}$ & $>2 \mu \mathrm{g} / \mathrm{kg}$ \\
\hline ZONE 1 & $0.63 \pm 0.39 \mathrm{~b}$ & $0.05-12.1$ & 15 & 5 \\
ZONE 2 & $1.36 \pm 1.30 \mathrm{a}$ & $0.05-14.7$ & 6 & 13 \\
ZONE 3 & $0.41 \pm 0.40 \mathrm{~b}$ & $0.05-3.87$ & 24 & 2 \\
ZONE 4 & $0.75 \pm 0.70 \mathrm{ab}$ & $0.05-9.91$ & 12 & 9 \\
ZONE 5 & $0.68 \pm 0.60 \mathrm{~b}$ & $0.05-9.21$ & 12 & 7 \\
ZONE 6 & $0.77 \pm 0.70 \mathrm{ab}$ & $0.05-8.79$ & 21 & 5 \\
AVERAGE & $0.69 \pm 0.60 \mathrm{~b}$ & $0.05-14.7$ & 15 & 6 \\
\hline
\end{tabular}


LD is Limit of Detection : $0.05 \mu \mathrm{g} / \mathrm{kg}$.

$2 \mu \mathrm{g} / \mathrm{kg}$ is maximum value set by the European Commission.

The averages of the same column followed by the same letter are not significantly different $(\mathrm{p}<0.05)$.

\subsection{Distribution of OTA Based on Cocoa Beans Grades}

OTA levels in terms of cocoa beans grades are presented in Table 7. Grade I (GI) cocoa beans had average OTA levels ranging from 0.67 to $0.87 \mu \mathrm{g} / \mathrm{kg}$ with an average of $0.74 \mu \mathrm{g} / \mathrm{kg}$. Statistical analysis revealed no significant difference $(\mathrm{p}<5 \%)$ as indicated in Table 7. Samples classified Grade II (GII) had OTA levels varying between 0.24 and $2.07 \mu \mathrm{g} / \mathrm{kg}$ with an average of $0.61 \mu \mathrm{g} / \mathrm{kg}$. Statistical analysis revealed a significant difference $(\mathrm{p}<5 \%)$ between these averages. Samples considered as Low-grade cocoa beans presented OTA levels comprised between 0.41 and $0.88 \mu \mathrm{g} / \mathrm{kg}$ with an average of $0.75 \mu \mathrm{g} / \mathrm{kg}$. Statistical analysis also revealed a significant difference $(\mathrm{p}<5 \%)$.

Table 7. Ochratoxin A levels in terms of Ivory Coast cocoa beans grades (Concentration: $\mu \mathrm{g} / \mathrm{kg}$ )

\begin{tabular}{llll}
\hline ZONES & GRADE I & GRADE II & LOW-GRADE \\
\hline ZONE 1 & $0.67 \pm 0.60 \mathrm{a} \alpha$ & $0.48 \pm 0.40 \mathrm{bc} \alpha$ & $0.84 \pm 0.80 \mathrm{ab} \alpha$ \\
ZONE 2 & $0.87 \pm 0.80 \mathrm{a} \alpha$ & $2.07 \pm 2.00 \mathrm{a} \alpha$ & $0.71 \pm 0.33 \mathrm{ab} \alpha$ \\
ZONE 3 & $0.69 \pm 0.59 \mathrm{a} \alpha$ & $0.24 \pm 0.23 \mathrm{c} \beta$ & $0.41 \pm 0.27 \mathrm{~b} \alpha \beta$ \\
ZONE 4 & $0.83 \pm 0.80 \mathrm{a} \alpha$ & $0.58 \pm 0.50 \mathrm{bc} \alpha$ & $0.88 \pm 0.80 \mathrm{a} \alpha$ \\
ZONE 5 & $0.75 \pm 0.68 \mathrm{a} \alpha$ & $0.53 \pm 0.49 \mathrm{bc} \alpha$ & $0.77 \pm 0.70 \mathrm{ab} \alpha$ \\
ZONE 6 & $0.86 \pm 0.80 \mathrm{a} \alpha$ & $0.93 \pm 0.90 \mathrm{ab} \alpha$ & $0.51 \pm 0.48 \mathrm{ab} \alpha$ \\
AVERAGE & $0.74 \pm 0.70 \mathrm{a} \alpha$ & $0.61 \pm 0.57 \mathrm{bc} \alpha$ & $0.75 \pm 0.70 \mathrm{ab} \alpha$ \\
\hline
\end{tabular}

Means followed by the same letters do not differ significantly at $\mathrm{p}<0.05$.

The letters $\mathrm{a}, \mathrm{b}$ and $\mathrm{c}$ refers to a comparison of sampling sites while the letter $\alpha$ and $\beta$ relates to a comparison of grades.

\subsection{Assessment of the Variation of Marketability Criteria and OTA Levels}

Figure 1a shows the variation in the marketability of cocoa beans during the harvest season. The percentage of exportable lots ranged from $50 \%$ to $100 \%$ during the main season (November to March) and from $0 \%$ to $100 \%$ for the campaign through April to July (intermediate campaign). This percentage is different from one zone to another as well as from one month to another. For the main season, all zones have a month of very high amount of production apart from area 2 which has three months of high production: November, February and March. The same phenomenon is observed during the intermediate campaign where areas 1 and 4 have two months of high production: April and July.

Figure $1 \mathrm{~b}$ shows the variation in Ivorian cocoa beans OTA levels during the harvest season. The average concentrations of OTA ranged from 0.18 to $3.94 \mu \mathrm{g} / \mathrm{kg}$ for the main season and from 0.18 to $0.99 \mu \mathrm{g} / \mathrm{kg}$ for the intermediate campaign.

The study on the homogeneity of means by a two-way analysis of variance (period and sampling sites), through the F-test revealed a significant difference $(\mathrm{p}<5 \%)$. For the sampling sites, the difference is observed in January between zones 1 and 2 for the main season. OTA concentrations remain the same during the intermediate campaign whatever the zone. For sampling periods, a significant difference is observed in zone 1 (January and March) and between all zones during January, February and March during the main season. Concentrations remain the same for the intermediate campaign whatever the month considered. 


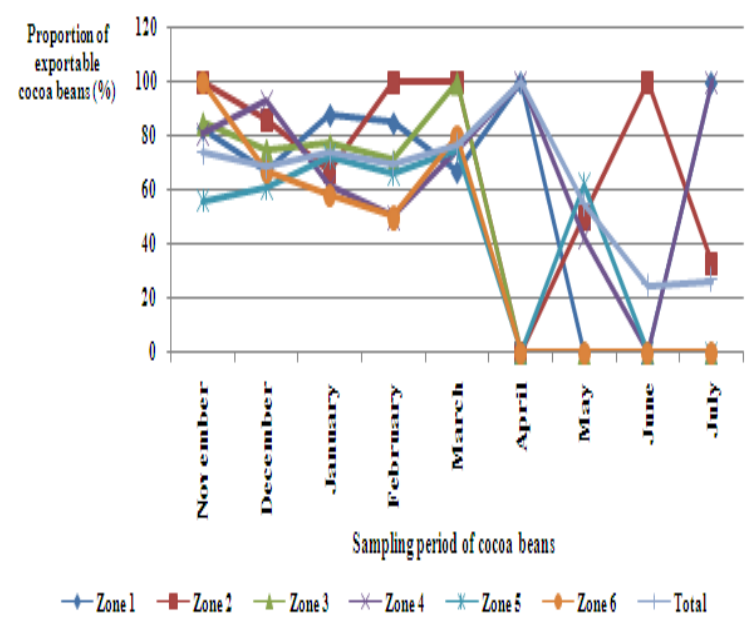

Figure 1a. Variation of the proportion of exportable cocoa beans during the harvest season

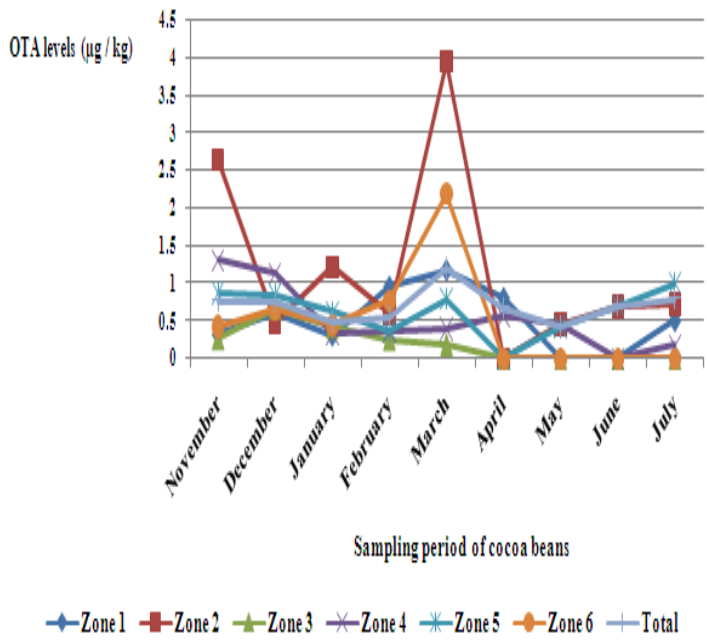

Figure 1b.Variation of OTA levels in Ivorian cocoa beans during the harvest season

Figure 1. Variations of OTA levels and exportable cocoa beans in Ivorian cocoa beans during the harvest season

\subsection{Assessment of the Variation of OTA Levels in Terms of the Marketability Criteria}

Table 8 shows the variation of OTA levels in terms of the merchantability criteria. The average concentrations of OTA ranged from 0.49 to $1.21 \mu \mathrm{g} / \mathrm{kg}$ for the main season (November to March) and from 0.43 to $0.80 \mu \mathrm{g} / \mathrm{kg}$ for the intermediate campaign (through April to July). A significant difference was observed between these average concentrations $(\mathrm{p}<5 \%)$. The highest OTA levels during the main season are observed in November, December and March, while OTA levels are fairly homogeneous for the intermediate campaign. Moisture content varied between 8.0 and $9.4 \%$ for the main season and between 5.0 and $9.0 \%$ for the intermediate season. Statistical analysis revealed a significant difference at $5 \%$ risk. For the main season, the highest moisture content were observed in November and December. Regarding the graining, it varies between 91 and 121 beans per $100 \mathrm{~g}$ of cocoa beans during the main season and between 119 and 133 beans per $100 \mathrm{~g}$ of cocoa beans during the intermediate campaign. The advocated number of beans per $100 \mathrm{~g}$ of cocoa beans is 105 . Values lower to this set value are mainly observed at the beginning of the main season (November, December and January).

Table 8. Variation of marketability criteria and OTA levels

OTA Levels ( $\mu \mathrm{g} / \mathrm{kg}$ )Moisture (\%)Graining (Beans/100g)Grade I (\%)Grade II (\%)Low-Grade (\%)

\begin{tabular}{|c|c|c|c|c|c|c|}
\hline \multicolumn{2}{|c|}{ November0.77 $\pm 0.70 \mathrm{abc}$} & $9.3 \pm 2.1 \mathrm{a}$ & $91 \pm 6$ e & 30 & 11 & 16 \\
\hline \multicolumn{2}{|c|}{ December $0.75 \pm 0.70 \mathrm{abc}$} & $9.4 \pm 2.6 \mathrm{a}$ & $94 \pm 6 d$ & 31 & 20 & 26 \\
\hline January & $0.49 \pm 0.40 \mathrm{bc}$ & $8.0 \pm 2.4 \mathrm{bc}$ & $93 \pm 6 \mathrm{~d}$ & 16 & 29 & 19 \\
\hline February & $0.55 \pm 0.50 \mathrm{bc}$ & $9.0 \pm 3.1 \mathrm{ab}$ & $111 \pm 16 \mathrm{c}$ & 12 & 22 & 18 \\
\hline March & $1.21 \pm 0.80 \mathrm{a}$ & $9.0 \pm 2.9 \mathrm{ab}$ & $121 \pm 17 b$ & 6 & 13 & 7 \\
\hline April & $0.68 \pm 0.59 \mathrm{abc}$ & $5.1 \pm 1.6 \mathrm{c}$ & $119 \pm 1 \mathrm{bc}$ & 1 & 0 & 0 \\
\hline May & $0.43 \pm 0.17 \mathrm{c}$ & $9.0 \pm 2.5 \mathrm{ab}$ & $133 \pm 10 \mathrm{a}$ & 3 & 3 & 6 \\
\hline June & $0.70 \pm 0.65 \mathrm{abc}$ & $8.4 \pm 1.1 \mathrm{ab}$ & $127 \pm 9 \mathrm{a}$ & 0 & 1 & 3 \\
\hline July & $0.80 \pm 0.52 \mathrm{ab}$ & $8.5 \pm 1.2 \mathrm{ab}$ & $125 \pm 23 \mathrm{a}$ & 1 & 1 & 5 \\
\hline \multicolumn{4}{|c|}{ Percentage for each grade } & 100 & 100 & 100 \\
\hline
\end{tabular}

In a given column, the averages followed by the same letter are not significantly different at $\mathrm{p}<0.05$. 
Concerning the classification in grades, the percentage of Grade I cocoa beans was between 6 and 31\% for the main season and between 0 and 3\% for the intermediate season. The percentage of Grade II cocoa beans varied between 11 and $29 \%$ for the main season and between 0 and 3\% for the intermediate season. The percentage of Low-Grade cocoa beans was between 7 and $26 \%$ for the main season and between 0 and $6 \%$ for the intermediate season. For the main season, the proportion of Low-Grade cocoa beans are similar: November (16\%), December (26\%), January (19\%) and February (18\%). During the intermediate campaign, the highest proportion of Low-Grade cocoa beans are observed in May (6\%) and July (5\%).

\subsection{Mapping of the Marketability and OTA Levels in Ivorian Cocoa Beans in Terms of the Production Areas}

From the data of the present study, a map summarizing the quality of Ivorian cocoa beans has been designed (Figure 2). This map indicated that zone 3 had the best beans in contrast to zone 2 which had the highest proportion of beans of poor quality.

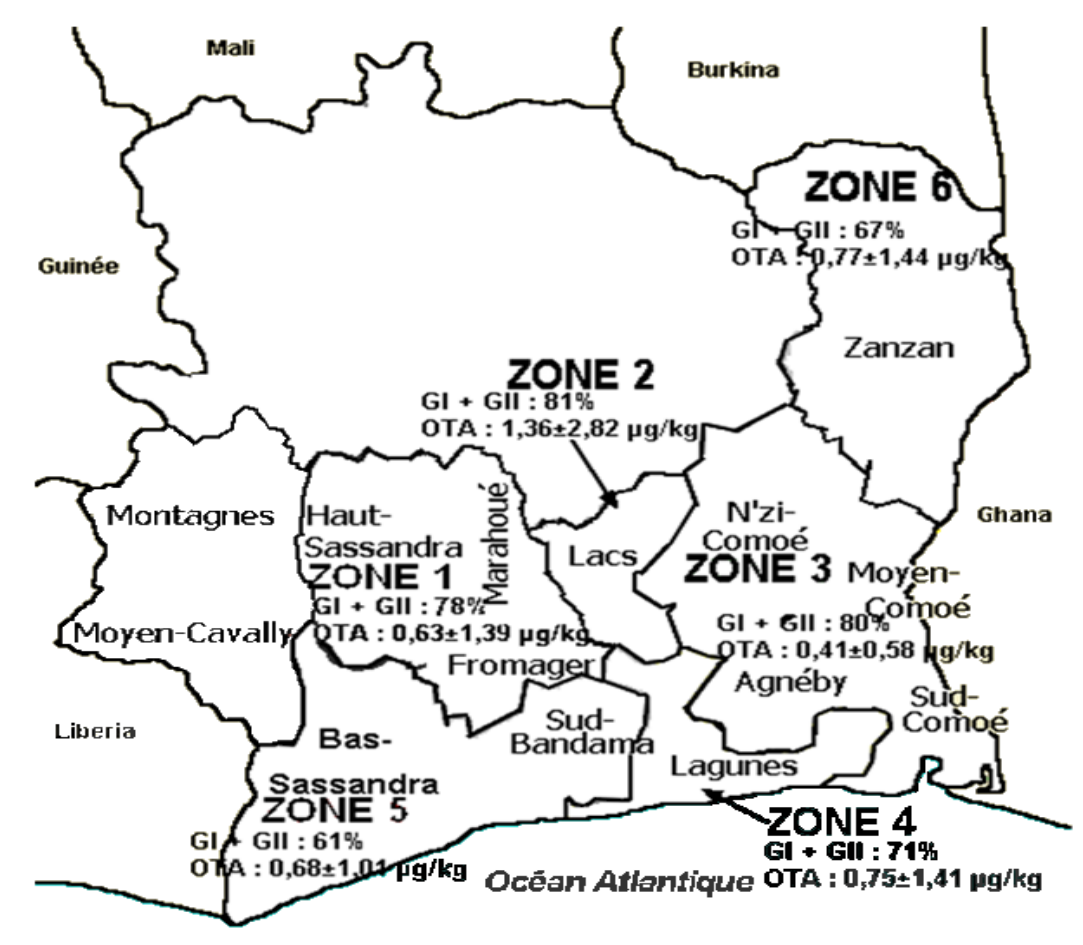

Figure 2. Map of Ivory Coast cocoa beans quality in terms of the zones of production

\section{Discussion}

If we take into account the recommended values for moisture content, graining, and grading, the proportion of exportable lots of cocoa beans was respectively $44 \%, 73 \%$ and $70 \%$. All zones had samples with moisture content above the limit set by the Ivorian Coffee and Cocoa stock exchange (BCC, 2009). This points out the recurrent problem of poor drying or moisture taking during transportation or storage in warehouses (Sackou k. J., et al., 2007; CA, 2011). Indeed, to achieve their goal buyers are compelled to buy wet beans (CA, 2011). This fact is corroborated by the high proportion of lots with moisture content above the standard that is observed in the main season, because of tremendous pressure and competition (CA, 2011). The results related to the graining are similar: Sackou et al. (2007) observed that farmers did not practice a sort of flat beans responsible for raising the graining (BCC, 2009), simply because buyers are gunning for quantity, not for quality. By putting into effect good production practices, producers could eliminate more efficiently beans of low quality (Sackou k. J., et al., 2007; CA, 2011).

The European Union advocates $2 \mu \mathrm{g} / \mathrm{kg}$ as the maximum value for OTA in cocoa beans (CA, 2011). Zones 2, 4 and 5 presented respectively $87 \%, 91 \%$ and $93 \%$ of samples with OTA levels complying with this standard. All production areas considered, $94 \%$ of samples complied with this maximum value. Contamination levels of OTA in cocoa beans revealed a variable trend in the production areas. OTA levels in exportable beans (Grade I and 
Grade II) are similar to those of non-tradable lots (Low-Grade). Thus, the poor marketability of a given lot is not necessarily related to the presence of OTA.

The study on the merchantability of cocoa beans through November to March showed that the months of November, December and January had the highest percentage of exportable beans. This is due to the dry season rather than to producers compliance with good agricultural practices. Furthermore, Low-Grade cocoa beans are uniformly distributed over the entire campaign with a peak in December.

Data from our study are in agreement with results obtained by Dembele et al. (2009). OTA highest levels occurred in November, December and March, that is, at the beginning and end of the main season.

\section{Conclusion}

This study was initiated to establish a map of OTA levels in Ivorian cocoa beans and analyze the parameters of merchantability in the production areas. It revealed that the sanitary quality was better than the marketability of cocoa beans in the areas of production and that moisture content remained the main worry farmers had to contend with. Both farmers and buyers could work together to improve cocoa beans marketability by doing their utmost to apply good manufacturing and purchasing practices. In this regard, the political authorities and all the other structures involved in the sector of cocoa should provide farmers with a better training. This would undoubtedly allow them to understand the issue of quality. This study also allowed to map the quality of cocoa beans in the production areas. This map is only a representation of a situation at a given time and should help to take up decisions relevant to the application of good production and postharvest processing practices. Studies on the relationship between the quality of cocoa beans from production areas to export sites (mainly ports) should also be carried out.

\section{References}

Association of Official Analytical Chemists. (AOAC), (1990). Official methods of analysis. In Association of Official Analytical Chemists. (13th ed.). Arlington, VA, USA.

Bastide, P., Fourny, G., Durand, N., Petithuguenin, P., Guyot, B., Gilmour, M., \& Lindblom, M. (2006). Identification of sources of Ochratoxin A during post-harvest cocoa processing: influence of harvest quality and Climatic factors. Report of 15th International Cocoa Research Conference, San Jose, Costa Rica.

Bonjean, C. A., \& Bruns, J. L. (2001). Mode d'organisation des filières et lutte contre la pauvreté: les cas du coton et du cacao. Rapport du Ministère des Affaires Etrangères, p. 144.

Bonjean, C. A., \& Bruns, J. F. (2008). Pouvoir de marché dans la filière cacao: hypothèse de Prebisch-Singer revisité. Economie Prevision, 186, 133-144.

Boorman, G. A., Hong, H. L., Dieter, M. P., Hayes, H. T., Pohland, A. E., Stack, M., \& Luster, M. I. (1984). Myelotoxicity and macrophage alteration in mice exposed to ochratoxin A. Toxicol. Appl. Pharmacol, 72, 304-312. http://dx.doi.org/10.1016/0041-008X(84)90315-6

Bourse du Café et du Cacao (BCC). (2009). Qualité du cacao.

Castegnaro, M. (1999). Risques cancérogènes. In Evaluation et gestion du risque. Technique et Documentation, Lavoisier, Paris, pp. 121-140.

Castegnaro, M., Mohr, U., Pfohl-leszkowicz, A., Esteve, J., Steinmann, J., Tilmann, T., Michelon, J., \& Bartsch, H. (1998). Sex and Strain specific induction of renal tumours by ochratoxin A in rats correlates with DNA $\begin{array}{llllll}\text { adduction. } & \text { Int. } & J & \text { Cancer, } & 77, & 70-75 \text {. }\end{array}$ http://dx.doi.org/10.1002/(SICI)1097-0215(19980703)77:1<70::AID-IJC12>3.0.CO;2-D

Codex Alimentarius (CA). (2011). Programme mixte FAO/OMS sur les normes alimentaires comité du codex sur les contaminants dans les aliments: document de travail sur l'ochratoxine a dans le cacao. Commission du Codex Alimentarius, CX/CF011/5/12, Janvier 2011, La Haye, Pays-Bas, p. 20.

Dembele, A., Coulibaly, A., Traoré, S. K., Mamadou, K., Silue, N., \& Touré, A. (2009). Détermination du niveau de contamination de l'ochratoxine A (OTA) dans les fèves de cacao à l'exportation. Tropicultura, 27, 26-30.

Dwidedi, P., \& Burns, R. B. (1984). Effect of ochratoxin A on immunoglobulins in broiler chicks. Res. Vet. Sci, $36,117-121$.

European Communities (EC). (2006). Règlement portant fixation des modes de prélèvement d'échantillons et des méthodes d'analyse pour le contrôle officiel des teneurs en mycotoxines des denrées alimentaires. Règlement N401/2006 du 23 février 2006. Journal Officiel de l’Union Eupéenne, 23. 
International Standard Organization (ISO). (1977). Cocoa beans-cut test. International Standard Organization $1114 / 1977$.

Lainé, K. (2001). Enquête sur les pratiques culturales dans les cacaoyères en Côte d'Ivoire. Rapport de projet PACCC/ICCO/Industrie sur l'amélioration de la qualité du cacao en Côte d'Ivoire, p 27.

Maaroufi, A., Achour, A., Zakhama, A., Ellouz, F. E., May, M., Creppy, E. E., \& Bacha, H. (1996). Human nephropathy related to ochratoxin A in Tunisia. J. Toxicol Toxin Rev, 15, 223-237.

Moré, J., \& Galtier, P. (1974). Toxicité de l'ochratoxine A. I. Effet embryotoxique et tératogène chez le rat. Ann. Rech. Vet, 5, 167-178.

Pauline, M., Dominique, G., Fontana-Tachon, A., Bernard, G., Pierre, R. T., \& Pierre, G. J. (2008). Filamentous Fungi Producing Ochratoxin A during cocoa processing in Cameroon. Int. J. Food. Microbiol, 121, 234-241. http://dx.doi.org/10.1016/j.ijfoodmicro.2007.11.017

Petrova-Bocharova, T., Chernozemsky, I. N., Castegnaro, M. (1988). Ochratoxin A in human blood in relation to Balkan endemic nephropathy and urinary system tumours in Bulgaria. Food addit. Contam, 5, 299-301. http://dx.doi.org/10.1080/02652038809373707

Ruf, F. (2000). Déterminants sociaux et économiques de la replantation. Oléagineux, Corps Gras. Lipides, 7 , 189-196.

Sackou, K. J., Oga, A. S. S., N'guessan, K., \& Kouadio, K. L. (2007). Les déterminants de la traçabilité hygiénique dans la filière cacao en Côte d'Ivoire. Cah. Santé Publ, 6, 17-26.

Waffa, E. W., Yahya, R. S., Sobh, M. A., Eraky, I., El Baz, M., El Gayar, H. A. M., Betbeder, A. M., Creppy, E. E. (1998). Human ochratoxicosis and nephropathy in Egypt: a preliminary study. Hum. Exp. Toxicol, 17, 124-129. http://dx.doi.org/10.1191/096032798678908369

World Health Organization (WHO). (1993). Ochratoxin A. In IARC Monographs on evaluation of carcinogenic risks to humans. Some naturally occuring substances, Food items and constituents, heterocyclic aromatic animes and mycotoxins. World health organization Report, 56, 489-521. 